\title{
Effects of hydrogen peroxide and alumina on surface characteristics of copper chemical-mechanical polishing in citric acid slurries
}

\author{
Jui-Chin Chen, Wen-Ta Tsai* \\ Department of Materials Science and Engineering, National Cheng Kung University, Tainan, Taiwan
}

Received 17 February 2004; received in revised form 18 May 2004; accepted 7 June 2004

\begin{abstract}
The roles of $\mathrm{H}_{2} \mathrm{O}_{2}$ and alumina on the changes of metal removal rate, surface passivation and surface morphology in citric acid (CA) base slurry in simulated $\mathrm{Cu}$ chemical-mechanical polishing (CMP) was investigated. X-ray photoelectron spectroscopy (XPS) analysis indicated that $\mathrm{H}_{2} \mathrm{O}_{2}$ assisted oxide formation while citric acid promoted anodic dissolution of copper in various slurries that contained $1 \mathrm{wt} \% \mathrm{Al}_{2} \mathrm{O}_{3}$. Atomic force microscopy (AFM) revealed that $\mathrm{Al}_{2} \mathrm{O}_{3}$ abrasive particles modified the surface morphology by inducing surface deformation. The results of open circuit potential (OCP) and removal rate measurements clearly demonstrated that there existed a synergistic effect due to the chelating and oxidizing agents in $\mathrm{Cu}$ CMP.
\end{abstract}

(c) 2004 Elsevier B.V. All rights reserved.

Keywords: Electropolishing; Surface properties; X-ray photoelectron spectroscopy (XPS); Atomic force microscopy (AFM)

\section{Introduction}

Kaufman et al. [1] proposed the chemical-mechanical polishing (CMP) model of tungsten and discussed the removal of $\mathrm{W}$ in terms of competition between an etching reaction that dissolves $\mathrm{W}$ as $\mathrm{WO}_{4}{ }^{-2}$ and a passivation reaction that oxidizes $\mathrm{W}$ to $\mathrm{WO}_{3}$ on the surface which was removed by a mechanical abrasion in the slurry. Kuo and Tsai [2-4] demonstrated that passive film formation and abrasion were importantly involved in Al CMP in a phosphoric acid base slurry. Studies of W CMP and Al CMP have indicated that the process of passivation film formation by chemical reaction and abrasion by mechanical action was key in removing $\mathrm{W}$ or $\mathrm{Al}$ during CMP. This mechanism has also been applied to explain Cu CMP [5,6]. However, Gutmann et al. [7] proposed a two-step model of $\mathrm{Cu} C \mathrm{CMP}$, involving mechanical abrasion of the copper surface followed by the removal of the abraded material from the vicinity of the surface. According to this model, the abraded material can be copper, copper oxide or other compounds of copper. This model suggests that the passivation of copper is not necessary for $\mathrm{Cu}$ CMP.

\footnotetext{
* Corresponding author. Tel.: +886 62757575 ext. 62927; fax: +88662754395.

E-mail address: wttsai@mail.ncku.edu.tw (W.-T. Tsai).
}

Despite the difference between the mechanisms mentioned above, a suitable oxidizing agent should be selected to enhance the $\mathrm{Cu}$ CMP rate. Several kinds of oxidizing agents, such as $\mathrm{H}_{2} \mathrm{O}_{2}[5,6,8], \mathrm{HNO}_{3}$ [7-11], $\mathrm{Fe}\left(\mathrm{NO}_{3}\right)_{3}$ [8,12], $\mathrm{NaClO}_{3}$ [13] and $\mathrm{KIO}_{3}$ [14], among others, have been used to form a passive film on a copper surface or to dissolve it into slurries. Although the oxidizing powers of these agents are known, the specific roles of these agents on $\mathrm{Cu}$ CMP were not as clear as that found in W CMP [1] or Al CMP [2-4,15]. Furthermore, Gutmann et al. [7] indicated that a combination of oxidizing agent and complexing agent would help to obtain a high solubility and dissolution rate of the abraded material in $\mathrm{Cu}$ CMP. In the case of $\mathrm{Cu} \mathrm{CMP}$ in $\mathrm{NH}_{4} \mathrm{OH}$ slurry, Steigerwald et al. [11] pointed out that $\mathrm{Cu}^{2+}$ ions were complexed with $\mathrm{NH}_{3}$ and the polishing rate was enhanced. Citric acid is also known to be a chelating agent for $\mathrm{Cu}^{2+}$ ions [16]. However, in 3 vol. $\% \mathrm{HNO}_{3}$ oxidizing slurry, highly concentrated citric acid was found to inhibit the etching rate in $\mathrm{Cu}$ CMP [9]. The co-existence of oxidizing and complexing agents in the slurry seems to have complicated effect on $\mathrm{Cu}$ CMP. This investigation, therefore, studies the effects of $\mathrm{H}_{2} \mathrm{O}_{2}$ and citric acid on the metal removal rate, surface composition and surface morphology of $\mathrm{Cu}$ in the slurry that contained $1 \mathrm{wt} . \% \quad \mathrm{Al}_{2} \mathrm{O}_{3}$ during and after simulated CMP. 


\section{Experimental}

\subsection{Specimen, slurry and polishing apparatus}

A pure copper rod (99.99\%) with a diameter of $2.5 \mathrm{~cm}$ was sliced into discs, each $0.8 \mathrm{~cm}$ thick. Each disc was mounted in epoxy resin with one surface exposed to air. The exposed copper surface was ground using $\mathrm{SiC}$ paper to a grit of 800 for subsequent measurements. The compositions and the $\mathrm{pH}$ values of the solutions and slurries studied in this investigation are summarized in Table 1. Two different concentrations of citric acid base slurries, namely 0.0078 and $0.5 \mathrm{M}$, were used. Powders of 1 wt. $\% \mathrm{Al}_{2} \mathrm{O}_{3}$ with an average particle size of $0.05 \mu \mathrm{m}$ were added as abrasive particles. The oxidizing agent $\mathrm{H}_{2} \mathrm{O}_{2}$ was added at a concentration of 9 vol.\% to some of the slurries.

A previously designed polishing instrument [2], simulating the mechanism of CMP, was modified and used in this work. The system consists of a $20.3 \mathrm{~cm}$ platen and a $7.6 \mathrm{~cm}$ carrier in diameter. The platen was bonded with a tank which held the slurry during polishing. The slurry was not refreshed throughout the test. The carrier on the top of the platen held three $\mathrm{Cu}$ discs $120^{\circ}$ apart. The platen and the carrier rotated in opposite directions at 100 and $10 \mathrm{rpm}$, respectively. The downward force between the specimen carrier and the platen could be varied from 0 to 8 psi. A Rodel IC- 1400 polish pad was attached to the platen for polishing. Fig. 1 schematically depicts the polisher used in this investigation. All the removal rate and open circuit potential (OCP) measurements were performed in this polisher.

\subsection{Removal rate measurements, surface analysis and OCP tests}

The weight loss measured after CMP was used to calculate the metal removal rate. For the case with a low metal removal rate, CMP was conducted for a period of three hours. The run for CMP was shortened to 20-60 min when a much high metal removal rate was observed. The total removal rate $\left(R_{\mathrm{t}}\right)$

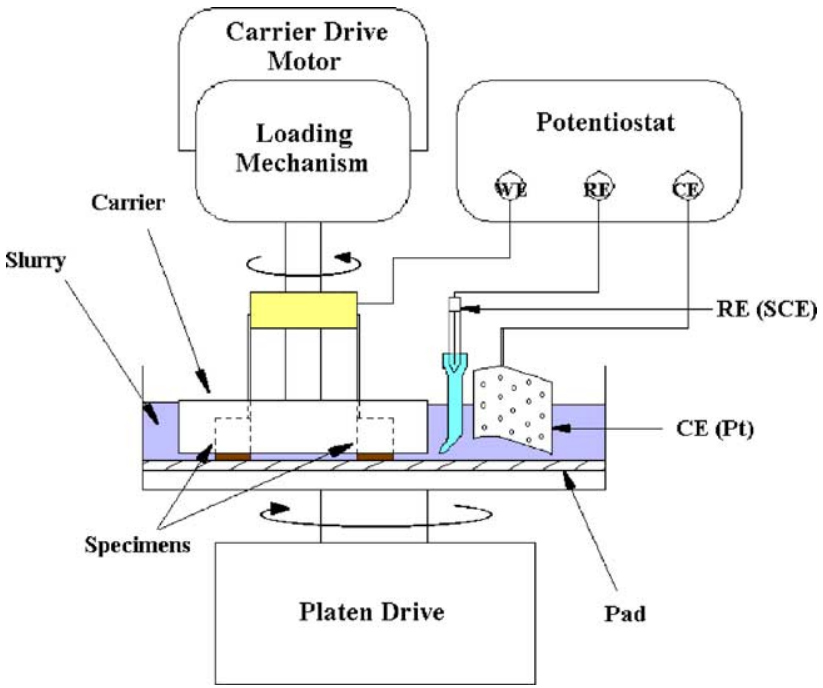

Fig. 1. Schematic diagram of the apparatus used in electrochemical and CMP tests.

for each CMP condition was calculated and averaged from three specimens.

In order to examine the effect of slurry composition on the surface chemistry change, a Fison (VG) ESCA210 X-ray photoelectron spectroscopy (XPS) was employed. The specimen was first immersed in a specific slurry for $60 \mathrm{~min}$. Then it was transferred for XPS analysis immediately after air drying. The excitation for XPS was by $\mathrm{Mg} \mathrm{K} \alpha$ radiation ( $h v$ $=1253.6 \mathrm{eV})$. The binding energies were calibrated to that of C (1S) at $284.6 \mathrm{eV}$.

The open circuit potentials were measured under stationary and during CMP as well. An EG\&G model 362 electrochemical system complied with a Yokogawa LR4110 recorder were used to monitor the potential during experiments. A saturated calomel electrode (SCE) and a sheet of platinum were used as the reference electrode and the counter electrode, respectively.

The surface morphology of copper after simulated CMP in the different slurries was observed by NT-MDT P7LS

Table 1

Compositions of the slurries used and the total removal rates of copper under simulated CMP at different contact pressures, with the upper carrier and lower platen rotated in opposite directions at 10 and $100 \mathrm{rpm}$, respectively

\begin{tabular}{|c|c|c|c|c|}
\hline \multirow[b]{2}{*}{ Designation of slurry } & \multirow[b]{2}{*}{ Slurry composition } & \multicolumn{3}{|c|}{ Removal rate $\left(\mathrm{nm} \mathrm{min}^{-1}\right)$} \\
\hline & & $3 \mathrm{psi}$ & $5 \mathrm{psi}$ & $8 \mathrm{psi}$ \\
\hline A & DI water $(\mathrm{pH}=6.4)$ & $\mathrm{ND}^{*}$ & - & - \\
\hline $\mathrm{B}$ & 9 vol. $\% \mathrm{H}_{2} \mathrm{O}_{2}(\mathrm{pH}=4.9)$ & $\mathrm{ND}^{*}$ & - & - \\
\hline $\mathrm{C}$ & $0.0078 \mathrm{M} \mathrm{CA}(\mathrm{pH}=2.6)$ & 33 & - & - \\
\hline $\mathrm{D}$ & 1 wt. $\% \mathrm{Al}_{2} \mathrm{O}_{3}(\mathrm{pH}=4.3)$ & 35 & - & - \\
\hline $\mathrm{E}$ & $0.0078 \mathrm{M} \mathrm{CA}+1$ wt. $\% \mathrm{Al}_{2} \mathrm{O}_{3}(\mathrm{pH}=2.7)$ & 52 & 74 & 87 \\
\hline $\mathrm{F}$ & $0.5 \mathrm{M} \mathrm{CA}+1$ wt. $\% \mathrm{Al}_{2} \mathrm{O}_{3}(\mathrm{pH}=1.5)$ & 53 & 60 & 74 \\
\hline G & 9 vol. $\% \mathrm{H}_{2} \mathrm{O}_{2}+1$ wt. $\% \mathrm{Al}_{2} \mathrm{O}_{3}(\mathrm{pH}=4.1)$ & 51 & - & - \\
\hline $\mathrm{H}$ & $0.0078 \mathrm{M} \mathrm{CA}+9$ vol. $\% \mathrm{H}_{2} \mathrm{O}_{2}(\mathrm{pH}=2.4)$ & 1045 & - & - \\
\hline I & $0.0078 \mathrm{M} \mathrm{CA}+9$ vol. $\% \mathrm{H}_{2} \mathrm{O}_{2}+1$ wt. $\% \mathrm{Al}_{2} \mathrm{O}_{3}(\mathrm{pH}=2.5)$ & 1435 & 3042 & 3487 \\
\hline $\mathrm{J}$ & $0.5 \mathrm{M} \mathrm{CA}+9$ vol. $\% \mathrm{H}_{2} \mathrm{O}_{2}+1$ wt. $\% \mathrm{Al}_{2} \mathrm{O}_{3}(\mathrm{pH}=1.4)$ & 5522 & 8897 & 11142 \\
\hline
\end{tabular}

\footnotetext{
$*$ Not detected.
} 
contact mode of atomic force microscope (AFM). The arithmetic mean surface roughness $\left(R_{\mathrm{a}}\right)$ was also evaluated by $\mathrm{AFM}$ and it was defined as following

$$
\begin{aligned}
R_{\mathrm{c}} & =\frac{1}{N_{x} N_{y}} \sum_{i=1}^{N_{x}} \sum_{j=1}^{N_{y}} z_{i j} \\
R_{\mathrm{a}} & =\frac{1}{N_{x} N_{y}} \sum_{i=1}^{N_{x}} \sum_{j=1}^{N_{y}}|z| \quad z=z_{i j}-R_{\mathrm{c}}
\end{aligned}
$$

where $z_{i j}$ is the height of parallel to the $Z$-axis and $R_{\mathrm{c}}$ is the mean surface height. $N_{x}$ and $N_{y}$ are the number of points along the $X$ - and $Y$-axis.

\section{Results and discussion}

\subsection{Removal rate of $\mathrm{Cu}$}

The total removal rates of copper after simulated CMP in various slurries with different contact pressures are listed in Table 1 . At a contact pressure of 3 psi, no measurable weight loss was obtained in plain de-ionized (DI) water with or without 9 vol. $\% \mathrm{H}_{2} \mathrm{O}_{2}$ added. In either $0.0078 \mathrm{M} \mathrm{CA}$ solution (solution C) or in DI water with 1 wt. $\% \mathrm{Al}_{2} \mathrm{O}_{3}$ (slurry D), the removal rate was low and almost the same. In $1 \mathrm{wt} . \% \mathrm{Al}_{2} \mathrm{O}_{3}$ slurry, adding only citric acid (slurry $\mathrm{E}$ or $\mathrm{F}$ ) or $\mathrm{H}_{2} \mathrm{O}_{2}$ (slurry G) slightly increased the removal rate to about $50 \mathrm{~nm} \mathrm{~min}^{-1}$. However, a dramatic increase in the removal rate occurred in the presence of both chelating and oxidizing agents. The contribution of the $\mathrm{Al}_{2} \mathrm{O}_{3}$ abrasive particles to the increase in removal rate also became noticeable. As shown in Table 1, the highest removal rate at a pressure of 3 psi was measured in the $0.5 \mathrm{M} \mathrm{CA}+9$ vol. $\% \mathrm{H}_{2} \mathrm{O}_{2}+1$ wt. $\% \mathrm{Al}_{2} \mathrm{O}_{3}$ slurry. The results clearly indicate that a synergistic effect due to the chelating and oxidizing agents existed in copper CMP. Although the $\mathrm{pH}$ of each slurry was different, comparing the removal rate in slurry $\mathrm{F}(\mathrm{pH}=1.5)$ with those in slurries $\mathrm{E}(\mathrm{pH}=2.7)$ and $\mathrm{G}(\mathrm{pH}=4.1)$ showed that the $\mathrm{pH}$ value insignificantly affected the metal removal rate.

The above results indicate that in the absence of oxidizing agent (slurries $\mathrm{A}, \mathrm{C}$ and $\mathrm{D}$ ), the mechanical contribution to the total removal rate was negligible. The presence of a highly oxidizing agent, such as $\mathrm{H}_{2} \mathrm{O}_{2}$, favored the formation of oxide (mainly $\mathrm{CuO}$ as will be described later by XPS). However, the removal rate in slurry $\mathrm{G}$ was also quite low $\left(51 \mathrm{~nm} \mathrm{~min}{ }^{-1}\right)$, indicating that the breakdown or abrasion of the oxide was insufficient to obtain a high removal rate of copper. The chelating effect on accelerating the dissolution of $\mathrm{CuO}$ in perchloric, sulfuric, nitric or hydrochloric acid solutions has been pointed out by Majjima et al. [17]. It was thus postulated (as demonstrated in slurries $\mathrm{H}-\mathrm{J}$ of Table 1) that the complexing of copper oxide with citric acid might also assist the etching rate in Cu CMP. In other words, a two-step model proposed by Gutmann et al. [7] could be

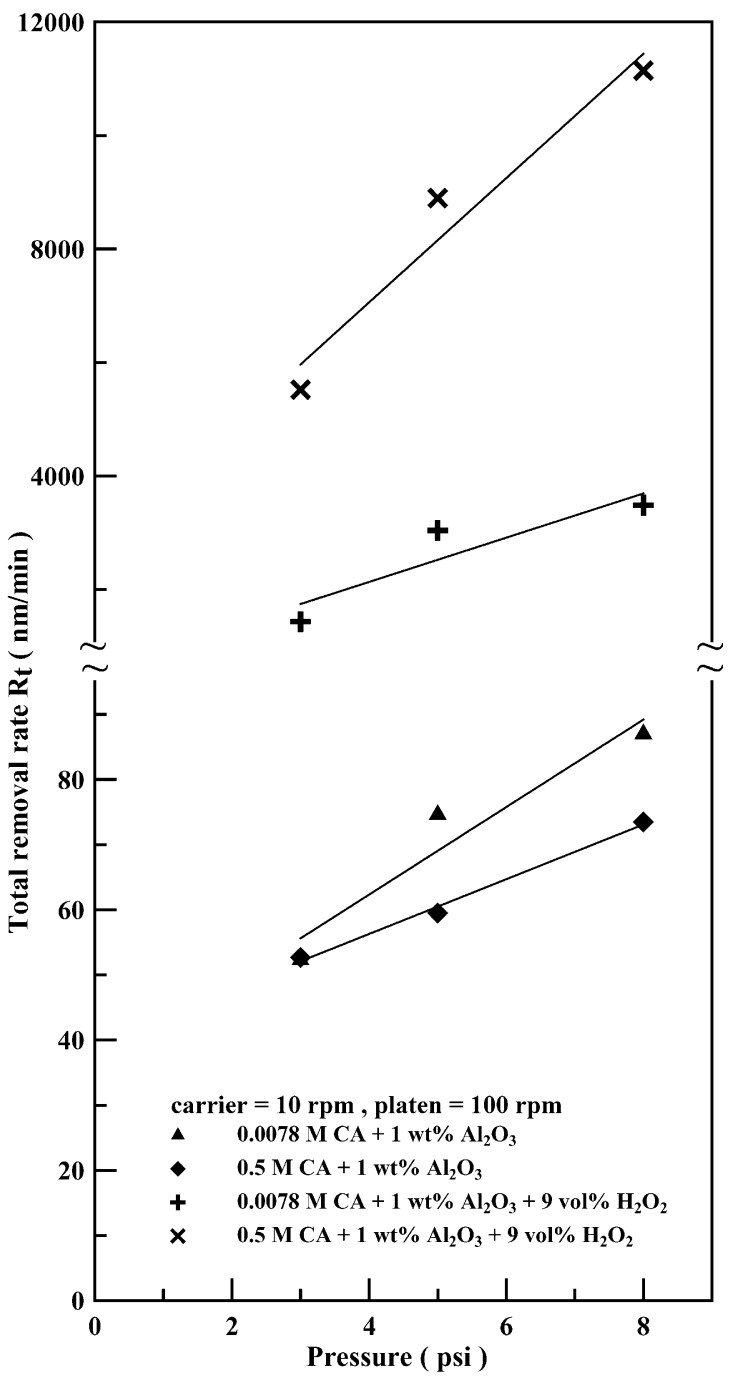

Fig. 2. Variations of total removal rate with contact pressure for copper under simulated CMP in different slurries.

applied to describe the process of $\mathrm{Cu} \mathrm{CMP}$ in the slurries used in this investigation.

As revealed in Table 1, the metal removal rate also increased with contact pressure. The effect of contact pressure was more pronounced when both the chelating and oxidizing agents were present simultaneously. The maximum copper removal rate $\left(11142 \mathrm{~nm} \mathrm{~min}^{-1}\right)$ was obtained in $0.5 \mathrm{M} \mathrm{CA}$ +9 vol. $\% \mathrm{H}_{2} \mathrm{O}_{2}+1 \mathrm{wt} . \% \mathrm{Al}_{2} \mathrm{O}_{3}$ slurry at a contact pressure of 8 psi. Fig. 2 depicts the effect of contact pressure on the copper removal rate in some slurries studied in this investigation. Most metal CMP satisfies the Preston relation,

$R=K_{p} \times P \times V$

where $R$ is the metal removal rate, $K_{p}$ is a constant, $P$ is the contact pressure, and $V$ is the relative velocity between the surface and the abrasive material such as the pad $[3,10,12,18]$. Under constant carrier and platen rotating speeds, the linear relationship between the copper removal rate and the contact pressure (Fig. 2) stated in the Preston 


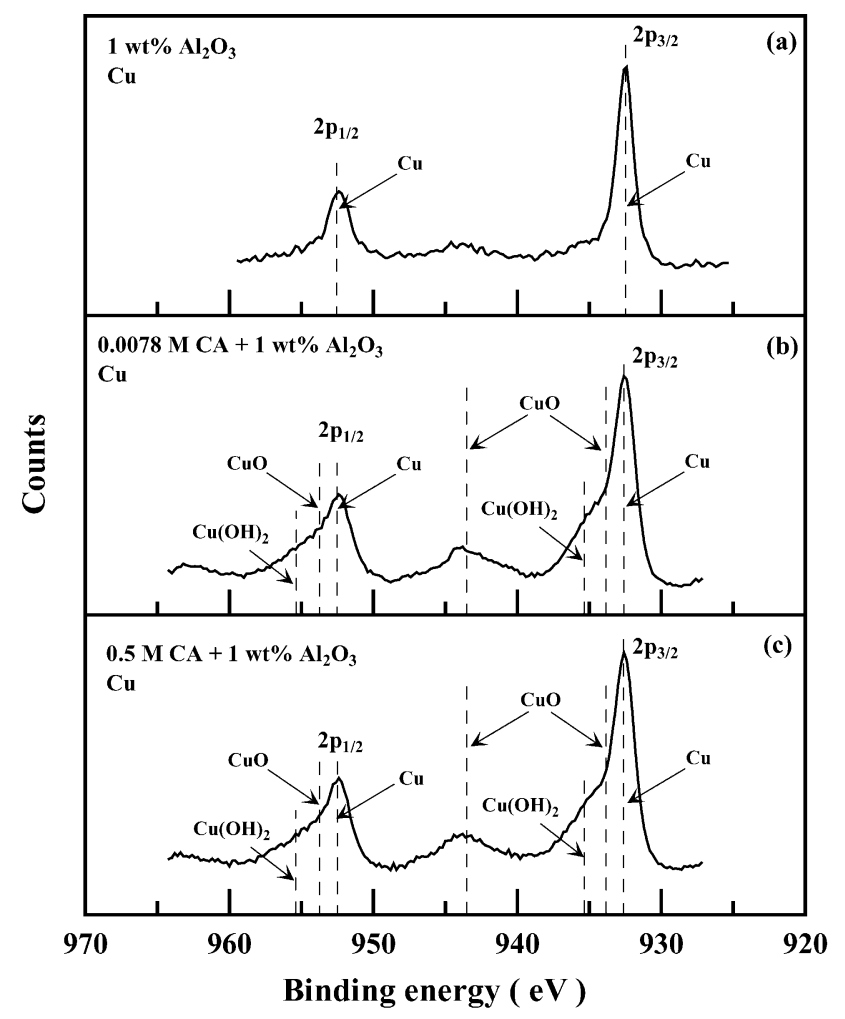

Fig. 3. XPS spectra of $\mathrm{Cu} 2 \mathrm{p}_{3 / 2}$ and $2 \mathrm{p}_{1 / 2}$ for $\mathrm{Cu}$ after immersion for $60 \mathrm{~min}$ in different slurries: (a) $1 \mathrm{wt} \% \mathrm{Al}_{2} \mathrm{O}_{3}$; (b) $0.0078 \mathrm{M} \mathrm{CA}+1 \mathrm{wt} . \%$ $\mathrm{Al}_{2} \mathrm{O}_{3}$ and (c) $0.5 \mathrm{M} \mathrm{CA}+1$ wt. $\% \mathrm{Al}_{2} \mathrm{O}_{3}$.

equation was obeyed for $\mathrm{Cu}$ CMP in the slurries employed in this investigation.

\subsection{Surface analysis by XPS and AFM, and OCP tests}

The synergistic effect of chelating and oxidizing agents that enhances the copper removal rate might involve passivation on the copper surface. XPS analysis was thus performed to characterize the surface change for copper immersed in different slurries for $60 \mathrm{~min}$. Fig. 3 presents the spectra of $\mathrm{Cu} 2 \mathrm{p}_{3 / 2}$ and $2 \mathrm{p}_{1 / 2}$ for the specimens immersed in $1 \mathrm{wt} . \%$ $\mathrm{Al}_{2} \mathrm{O}_{3}$ slurries with 0.0078 and $0.5 \mathrm{M} \mathrm{CA}$, without $\mathrm{H}_{2} \mathrm{O}_{2}$ added. In plain $1 \mathrm{wt} . \% \mathrm{Al}_{2} \mathrm{O}_{3}$ slurry, the sharp peaks at 932.5 and $952.5 \mathrm{eV}$, corresponding to $2 \mathrm{p}_{3 / 2}$ and $2 \mathrm{p}_{1 / 2}$ spectra for $\mathrm{Cu}[19,20]$, demonstrated that only metallic copper existed while the oxidation of copper was negligible (Fig. 3a). In the presence of 0.0078 and $0.5 \mathrm{M} \mathrm{CA}$, as shown in Figs. $3 \mathrm{~b}$ and c, the peaks at around $932.5 \mathrm{eV}$ became broadened. This revealed that $\mathrm{CuO}, \mathrm{Cu}(\mathrm{OH})_{2}$ and metallic copper were present on the surface of the specimen. Adding 9 vol. $\% \mathrm{H}_{2} \mathrm{O}_{2}$ to either 1 wt. $\% \mathrm{Al}_{2} \mathrm{O}_{3}$ or $0.0078 \mathrm{M} \mathrm{CA}+1$ wt. $\% \mathrm{Al}_{2} \mathrm{O}_{3}$ slurry promoted the formation of $\mathrm{CuO}$. As shown in Figs. $4 \mathrm{a}$ and $\mathrm{b}$, the peaks at 933.5 and $935.2 \mathrm{eV}$ for $\mathrm{Cu} 2 \mathrm{p}_{3 / 2}$ and 953.5 and $955.2 \mathrm{eV}$ for $\mathrm{Cu} 2 \mathrm{p}_{1 / 2}$ demonstrated the formation of $\mathrm{CuO}$ and $\mathrm{Cu}(\mathrm{OH})_{2}$, respectively. The satellites near 943 and $963 \mathrm{eV}$ also confirmed the presence of $\mathrm{CuO}$. In both slurries,

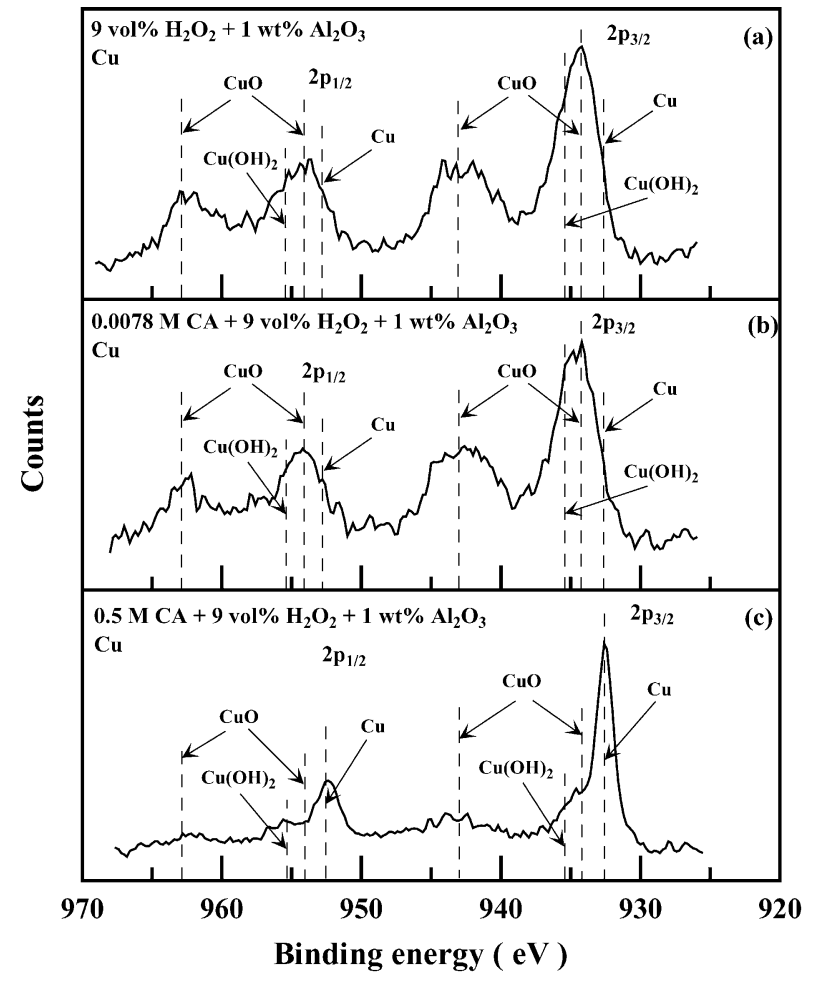

Fig. 4. XPS spectra of $\mathrm{Cu} 2 \mathrm{p}_{3 / 2}$ and $2 \mathrm{p}_{1 / 2}$ for $\mathrm{Cu}$ after immersion for $60 \mathrm{~min}$ in different slurries: (a) $1 \mathrm{wt} \% \quad \mathrm{Al}_{2} \mathrm{O}_{3}+9$ vol. $\% \quad \mathrm{H}_{2} \mathrm{O}_{2}$; (b) $0.0078 \mathrm{M} \mathrm{CA}+1$ wt. $\% \mathrm{Al}_{2} \mathrm{O}_{3}+9$ vol. $\% \mathrm{H}_{2} \mathrm{O}_{2}$ and (c) $0.5 \mathrm{M} \mathrm{CA}$ +1 wt. $\% \mathrm{Al}_{2} \mathrm{O}_{3}+9$ vol. $\% \mathrm{H}_{2} \mathrm{O}_{2}$.

the peaks corresponding to metallic copper disappeared, indicating that the oxide film was rather thick. Interestingly, as revealed in Fig. 4c, when the specimen was immersed in $0.5 \mathrm{M} \mathrm{CA}+9 \mathrm{vol} . \% \mathrm{H}_{2} \mathrm{O}_{2}+1 \mathrm{wt} . \% \mathrm{Al}_{2} \mathrm{O}_{3}$ slurry, the peak intensity of $\mathrm{CuO}$ was lowered and the peak of metallic copper reappeared with a high intensity. This result indicates that citric acid at a high concentration would retard oxide film formation. Meanwhile, the presence of an oxidizing agent $\left(\mathrm{H}_{2} \mathrm{O}_{2}\right)$ enhances the dissolution of copper into the slurry. The dissolved copper ions (mainly in the form of cupric ions) may be present in three different forms, free cupric ion, complexed cupric ion and cupric oxide. A higher concentration of citric acid allows more cupric ions to be adsorbed and complexed, resulting in a low concentration of free cupric ions in the slurry near the metal surface. Reducing the surface cupric ion concentration caused a reduction in the precipitation of cupric oxide, as demonstrated in Fig. 4c.

Fig. 5 shows the changes of open circuit potentials on the addition of 9 vol. $\% \mathrm{H}_{2} \mathrm{O}_{2}$ in citric acid base slurries. In the absence of $\mathrm{H}_{2} \mathrm{O}_{2}$, the open circuit potentials of copper were near or below $0 \mathrm{mV}$ under either static condition or CMP. Adding 9 vol. $\% \mathrm{H}_{2} \mathrm{O}_{2}$ to the slurry substantially increased the open circuit potential. As shown in Fig. 5, the increase in the open circuit potential was more pronounced in $0.0078 \mathrm{M}$ $\mathrm{CA}+1$ wt. $\% \mathrm{Al}_{2} \mathrm{O}_{3}$ slurry than that with $0.5 \mathrm{M} \mathrm{CA}$. It was in the latter slurry that the precipitation of cupric oxide was reduced, as revealed in Fig. 4c mentioned above. 


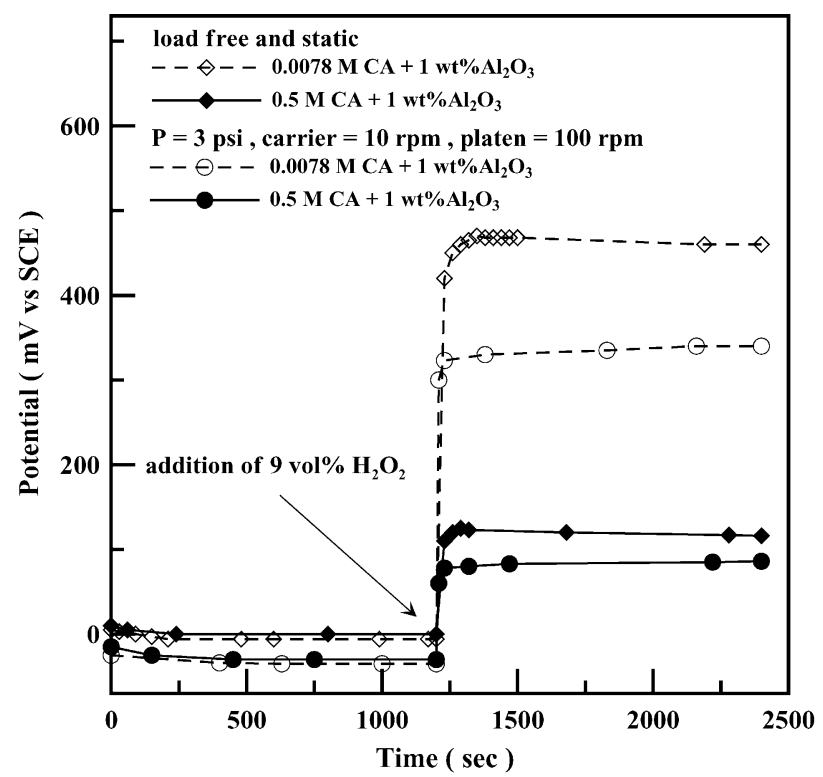

Fig. 5. Effects of $\mathrm{H}_{2} \mathrm{O}_{2}$ and loading conditions on the changes in open circuit potentials of copper in $\times \mathrm{M} \mathrm{CA}+1 \mathrm{wt} . \% \mathrm{Al}_{2} \mathrm{O}_{3}$ slurries.

As shown in Table 1, an extremely high removal rate was found in $0.5 \mathrm{M} \mathrm{CA}+9 \mathrm{vol} . \% \mathrm{H}_{2} \mathrm{O}_{2}+1 \mathrm{wt} . \% \mathrm{Al}_{2} \mathrm{O}_{3}$ slurry, about two orders of magnitude higher than those in slurries with citric acid or $\mathrm{H}_{2} \mathrm{O}_{2}$ alone (slurries $\mathrm{E}-\mathrm{G}$ ). The high removal rate was not attributed to dissolution, passivation and film breakdown as proposed by Kaufman et al. [1] since oxide film formation in this slurry was not favored. Instead, the high dissolution rate of copper, supported by the $\mathrm{H}_{2} \mathrm{O}_{2}$ oxidizing agent coupled with the high solubility of the cupric ions by chelating with a high concentration of citric ions, was the main cause of the extremely high removal rate observed.

Fig. 6 shows an AFM image of copper surface ground using $\mathrm{SiC}$ paper to a grit of 800 . A rough surface with a parallel pattern, caused by scratching during grinding, was observed. In the area examined, the surface roughness, measured as the arithmetic mean deviation of the profile $\left(R_{\mathrm{a}}\right)$, was $104 \mathrm{~nm}$. After CMP in various solutions or slurries, the surface roughnesses of the specimens were also measured.
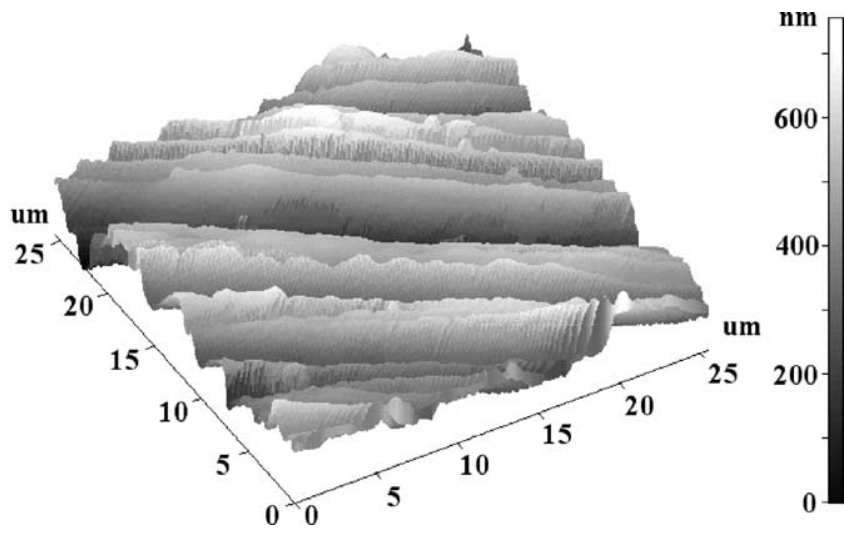

Fig. 6. Surface morphology of copper ground using $\mathrm{SiC}$ paper to a grit of 800 .

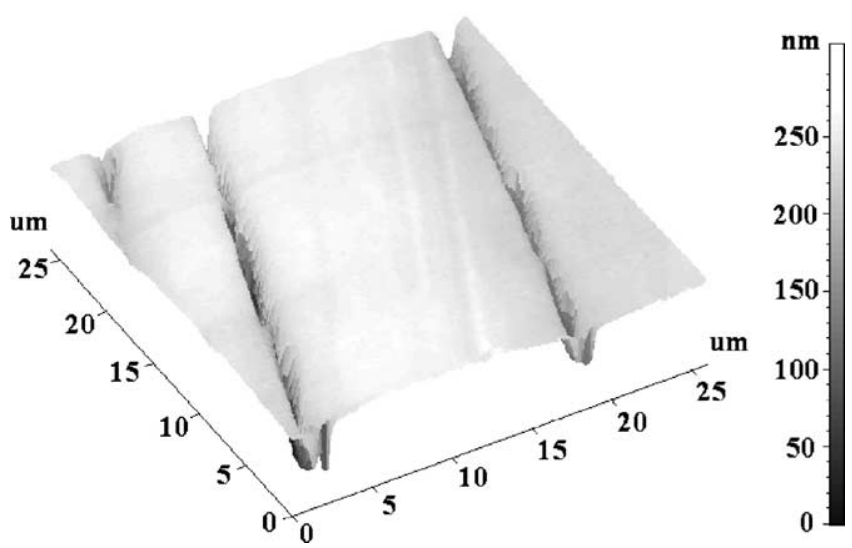

Fig. 7. Surface morphology of copper after simulated CMP in $0.0078 \mathrm{M}$ CA solution.

The values of $R_{\mathrm{a}}$ obtained at a contact pressure of 3 psi are listed in Table 2. In DI water, though the surface roughness was reduced as shown in Table 2, parallel scratches still remained on the surface after simulated CMP at a contact pressure of $3 \mathrm{psi}$ for $3 \mathrm{~h}$.

Fig. 7 depicts the surface morphology in $0.0078 \mathrm{M} \mathrm{CA}$ solution without abrasive particles. The surface roughness was

Table 2

Removal rate $\left(R_{\mathrm{t}}\right)$ and average roughness $\left(R_{\mathrm{a}}\right)$ of copper after simulated CMP in various solutions and slurries at 3 psi

\begin{tabular}{|c|c|c|c|}
\hline Slurry & & $R_{\mathrm{t}}\left(\mathrm{nm} \min ^{-1}\right)$ & $R_{\mathrm{a}}(\mathrm{nm})$ \\
\hline & Initial surface before CMP (\#800) & - & 104 \\
\hline A & DI water $(\mathrm{pH}=6.4)$ & $\mathrm{Nd}^{\mathrm{a}}$ & 78 \\
\hline B & 9 vol. $\% \mathrm{H}_{2} \mathrm{O}_{2}(\mathrm{pH}=4.9)$ & $\mathrm{Nd}^{\mathrm{a}}$ & 99 \\
\hline $\mathrm{C}$ & $0.0078 \mathrm{M} \mathrm{CA}(\mathrm{pH}=2.6)$ & 33 & 23 \\
\hline $\mathrm{D}$ & 1 wt. $\% \mathrm{Al}_{2} \mathrm{O}_{3}(\mathrm{pH}=4.3)$ & 35 & 12 \\
\hline $\mathrm{E}$ & $0.0078 \mathrm{M} \mathrm{CA}+1$ wt. $\% \mathrm{Al}_{2} \mathrm{O}_{3}(\mathrm{pH}=2.7)$ & 52 & 26 \\
\hline $\mathrm{F}$ & $0.5 \mathrm{M} \mathrm{CA}+1$ wt. $\% \mathrm{Al}_{2} \mathrm{O}_{3}(\mathrm{pH}=1.5)$ & 53 & 30 \\
\hline G & 9 vol. $\% \mathrm{H}_{2} \mathrm{O}_{2}+1$ wt. $\% \mathrm{Al}_{2} \mathrm{O}_{3}(\mathrm{pH}=4.1)$ & 51 & 3 \\
\hline $\mathrm{H}$ & $0.0078 \mathrm{M} \mathrm{CA}+9$ vol. $\% \mathrm{H}_{2} \mathrm{O}_{2}(\mathrm{pH}=2.4)$ & 1045 & 57 \\
\hline I & $0.0078 \mathrm{M} \mathrm{CA}+9$ vol. $\% \mathrm{H}_{2} \mathrm{O}_{2}+1$ wt. $\% \mathrm{Al}_{2} \mathrm{O}_{3}(\mathrm{pH}=2.5)$ & 1435 & 2 \\
\hline $\mathrm{J}$ & $0.5 \mathrm{M} \mathrm{CA}+9$ vol. $\% \mathrm{H}_{2} \mathrm{O}_{2}+1$ wt. $\% \mathrm{Al}_{2} \mathrm{O}_{3}(\mathrm{pH}=1.4)$ & 5522 & 352 \\
\hline
\end{tabular}

\footnotetext{
${ }^{\mathrm{a}}$ Not detected.
} 

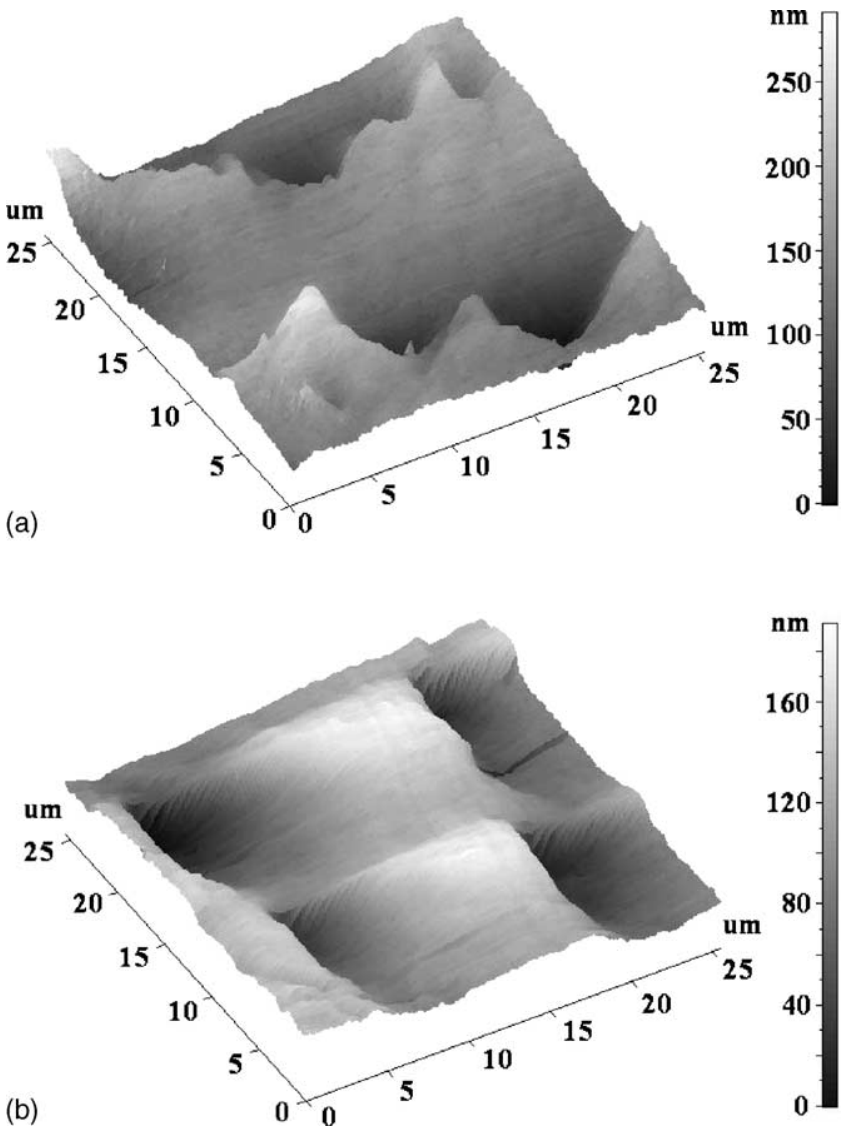

Fig. 8. Surface morphology of copper after simulated CMP in (a) $0.0078 \mathrm{M}$ $\mathrm{CA}+1$ wt. $\% \mathrm{Al}_{2} \mathrm{O}_{3}$ and (b) $0.5 \mathrm{M} \mathrm{CA}+1$ wt. $\% \mathrm{Al}_{2} \mathrm{O}_{3}$ slurries.

greatly reduced. However, a few parallel and deep grooves were observed on the surface. Adding $1 \mathrm{wt} . \% \mathrm{Al}_{2} \mathrm{O}_{3}$ to the citric acid solution further modified the surface morphology. Fig. 8a shows that the smooth plateau in Fig. 7 disappeared when $\mathrm{Cu}$ was polished in $0.0078 \mathrm{M} \mathrm{CA}+1 \mathrm{wt} . \%$ $\mathrm{Al}_{2} \mathrm{O}_{3}$ slurry. Instead, an eroded feature was seen after simulated CMP in such slurry. As the concentration of citric acid was increased to $0.5 \mathrm{M}, R_{\mathrm{a}}$ did not change much (Fig. 8b).

If CMP was simulated in the slurry with a composition of 9 vol. $\% \mathrm{H}_{2} \mathrm{O}_{2}+0.0078 \mathrm{M} \mathrm{CA}+1$ wt. $\% \mathrm{Al}_{2} \mathrm{O}_{3}$ (slurry I), a rather high removal rate $\left(1435 \mathrm{~nm} \mathrm{~min}^{-1}\right)$ and the lowest surface roughness $\left(R_{\mathrm{a}}=2 \mathrm{~nm}\right)$ were obtained. Fig. 9 shows the AFM image of a copper surface after polishing in such slurry. When the concentration of citric acid was increased to $0.5 \mathrm{M}$, the surface became very rough although the removal rate was substantially increased.

\subsection{Roles of citric acid, $\mathrm{H}_{2} \mathrm{O}_{2}$ and $\mathrm{Al}_{2} \mathrm{O}_{3}$}

Besides acting as a chelating agent, citric acid provides an acidic environment. However, the electrochemical dissolution associated with citric acid contributed only a little to the copper removal rate in plain $0.0078 \mathrm{M} \mathrm{CA}$ solution. Nev-

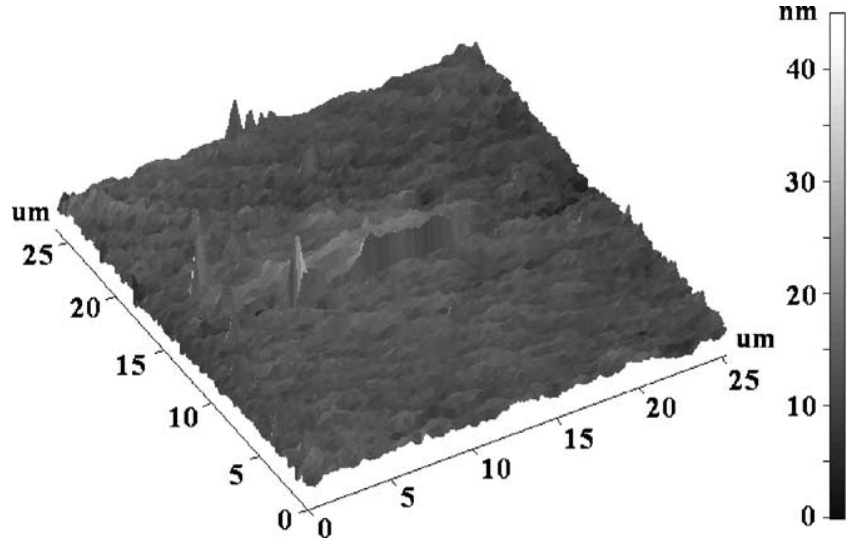

Fig. 9. Surface morphology of copper after simulated CMP in $0.0078 \mathrm{M}$ $\mathrm{CA}+9$ vol. $\% \mathrm{H}_{2} \mathrm{O}_{2}+1$ wt. $\% \mathrm{Al}_{2} \mathrm{O}_{3}$ slurry.

ertheless, the surface morphology could still be modified by the presence of citric acid, as noted in Fig. 7. Fig. 8 illustrates the joint effect of the simultaneous presence of citric acid and $\mathrm{Al}_{2} \mathrm{O}_{3}$ particles on surface morphologies, depicting erosion corrosion characteristics on the surface. Again, the low copper removal rate (about $50 \mathrm{~nm} \mathrm{~min}^{-1}$ ) indicated that mechanical effect dominated the surface roughness in the absence of oxidizing agent.

The XPS results showed that $\mathrm{H}_{2} \mathrm{O}_{2}$ would promote $\mathrm{CuO}$ formation in the slurry with low concentration $(0.0078 \mathrm{M})$ of citric acid. The dramatic reductions in surface roughness, found for copper under simulated CMP in slurries G and I might be associated with passivation assisted by $\mathrm{H}_{2} \mathrm{O}_{2}$. On the contrary, XPS analysis showed that slurry J with $0.5 \mathrm{M}$ of citric acid did not favor the formation of $\mathrm{CuO}$. In such a case, copper dissolution accelerated by the synergistic effect of citric acid and $\mathrm{H}_{2} \mathrm{O}_{2}$ overshadowed the influence of abrasive particles in modifying the surface morphology. As a result, a very high surface roughness was observed after simulated CMP in 9 vol. $\% \mathrm{H}_{2} \mathrm{O}_{2}+0.5 \mathrm{M} \mathrm{CA}+1$ wt. $\% \mathrm{Al}_{2} \mathrm{O}_{3}$ slurry.

The role of $\mathrm{Al}_{2} \mathrm{O}_{3}$ in $\mathrm{Cu}$ CMP in DI water and citric acid base slurries was revealed in Table 2. Since the removal rate of copper was only $35 \mathrm{~nm} \mathrm{~min}^{-1}$ in 1 wt. $\% \mathrm{Al}_{2} \mathrm{O}_{3}$ slurry, $\mathrm{Al}_{2} \mathrm{O}_{3}$ particles seemed mainly to cause surface plastic deformation rather than to abrade the metal away from the surface. The low surface roughness observed in $1 \mathrm{wt} . \%$ $\mathrm{Al}_{2} \mathrm{O}_{3}$ slurry suggests that the deformation process was advantageous in obtaining a smooth surface. Adding citric acid to $1 \mathrm{wt} . \% \quad \mathrm{Al}_{2} \mathrm{O}_{3}$ slurry increased surface roughness over that in plain $1 \mathrm{wt} . \% \mathrm{Al}_{2} \mathrm{O}_{3}$ slurry, but the roughness remained lower than that in DI water. Fig. 9 shows the beneficial effect of the $\mathrm{Al}_{2} \mathrm{O}_{3}$ particles in planarization, in co-existing with $0.0078 \mathrm{M} \mathrm{CA}$ and 9 vol. $\% \mathrm{H}_{2} \mathrm{O}_{2}$. However, in $0.5 \mathrm{M} \mathrm{CA}+9$ vol. $\% \mathrm{H}_{2} \mathrm{O}_{2}+1 \mathrm{wt} . \% \mathrm{Al}_{2} \mathrm{O}_{3}$ slurry, the beneficial effect of abrasive particle disappeared, probably because the copper dissolution rate was so high that the benefit due to deformation, provided by abrasive particles, was lost. 


\section{Conclusions}

The simultaneous presence of citric acid and $\mathrm{H}_{2} \mathrm{O}_{2}$, synergistically promoted the total copper removal rate in simulated CMP. Adding $\mathrm{H}_{2} \mathrm{O}_{2}$ substantial assisted the passivation of copper at low citric acid concentration. The existence of citric acid importantly participated in increasing copper dissolution by complexing the copper ions dissolved in the slurry. The complexing effect of citric acid increased with its concentration. XPS analysis showed that passivation of copper surface was not favored in the slurries with a high concentration of citric acid. Moreover, $\mathrm{Al}_{2} \mathrm{O}_{3}$ could modify the surface morphology, which was also dependent on the slurry composition. A suitable metal removal rate with low surface roughness could be obtained by compromising metal dissolution and abrasive effect in $\mathrm{Cu} \mathrm{CMP}$.

\section{Acknowledgements}

The authors would like to thank the National Science Council of the Republic of China, for financially supporting this research under Contract No. NSC 89-2216-E-006-077.

\section{References}

[1] F.B. Kaufman, D.B. Thompson, R.E. Broadie, M.A. Jaso, W.L. Guthrie, D.J. Pearson, M.B. Small, J. Electrochem. Soc. 138 (1991) 3460 .
[2] H.S. Kuo, W.T. Tsai, J. Electrochem. Soc. 147 (2000) 149.

[3] H.S. Kuo, W.T. Tsai, J. Electrochem. Soc. 147 (2000) 2136.

[4] H.S. Kuo, W.T. Tsai, Mater. Chem. Phys. 69 (2001) 53.

[5] S. Kondo, N. Sakuma, Y. Homma, N. Ohashi, PV 98-6, The Electrochemical Society Proceedings Series, Pennington, NJ, 1998, p. 195.

[6] D. Zeidler, Z. Stavreva, M. Plotner, K. Drescher, Microelectron. Eng. 33 (1997) 259.

[7] R.J. Gutmann, J.M. Steigerwald, L. You, D.T. Price, J. Neiynck, D.J. Duquette, S.P. Murarka, Thin Solid Film 270 (1995) 596.

[8] M.A. Fury, D.L. Scherber, M.A. Stell, MRS Bulletin, November 1995 , p. 61

[9] T.C. Hu, S.Y. Chiu, B.T. Dai, M.S. Tsai, I.C. Tung, M.S. Feng, Mater. Chem. Phys. 61 (1999) 169.

[10] R. Carpio, J. Farkas, R. Jairath, Thin Solid Film 266 (1995) 238.

[11] J.M. Steigerwald, S.P. Murarka, R.J. Gutmann, D.J. Duquette, Mater. Chem. Phys. 41 (1995) 217.

[12] Q. Luo, S. Ramarajan, S.V. Babu, Thin Solid Film 335 (1998) 160.

[13] Q. Luo, D.R. Campbell, S.V. Babu, Thin Solid Film 311 (1997) 177.

[14] Y. Li, S.V. Babu, Electrochem. Solid-State Lett. 4 (2001) G20.

[15] M. Fayolle, F. Romagna, Microelectron. Eng. 37-38 (1997) 135.

[16] R.S. Juang, F.C. Wu, R.L. Tseng, Water Res. 33 (1999) 2403.

[17] H. Majjima, Y. Awakura, T. Yazaki, Y. Chikamori, Metall. Trans. B 11B (1980) 209.

[18] L.M. Cook, J. Non-Cryst. Solid 120 (1990) 152.

[19] J. Itoh, T. Sasaki, T. Ohtsuka, Corros. Sci. 42 (2000) 1539.

[20] Y. Feng, W.K. Teo, K.S. Siow, K.L. Tan, A.K. Hsieh, Corros. Sci. 38 (1996) 369. 